\title{
A review of HIV in prisons in Nepal
}

\section{Dolan $\mathbf{K}^{1}$, Larney $\mathbf{S}^{\mathbf{1}}$}

${ }^{1}$ Program of International Research and Training, National Drug and Alcohol Research Centre, University of New South Wales, Australia

\begin{abstract}
Background: HIV in prisons is a serious public health concern. People in prison are at risk of contracting HIV through injecting drug use, unprotected sex and tattooing. However, most countries have largely neglected HIV prevention and care in prisons.

Objectives: The aim of this study is to review HIV prevention and care in Nepal's prisons

Materials and methods: This was carried out by Systematic review of published and grey literature.

Results: Nepal's National HIV Strategy acknowledges the importance of prisons in broader HIV prevention efforts. However, prison conditions are poor and there is no accurate information regarding HIV prevalence or risk behaviours among prisoners. HIV prevention interventions have largely been limited to ad hoc training workshops. Antiretroviral treatment is not available to HIV infected prisoners.

Conclusion: There is recognition in Government policy documents that prisons must be involved in efforts to stem the HIV epidemic. However, HIV prevention and care remains largely non-existent in Nepal's prisons. Efforts to obtain external funding to initiate and maintain programs such as drug dependency treatment and condom distribution are required. Attention could also be given to introducing alternatives to incarceration for less serious offenders and drug dependent offenders.
\end{abstract}

Key words: HIV, prison, Nepal

$\mathrm{H}$ IV prevalence in prisons is higher than in surrounding communities ${ }^{1}$. One reason for this is high levels of incarceration of populations who already have elevated levels of HIV infection, such as people who inject drugs $^{2}$. Additionally, people acquire HIV infection while in prison, through injecting drug use $\mathrm{e}^{3-6}$, unprotected $\operatorname{sex}^{7}$, tattooing ${ }^{7,8}$ and other body modification practices such as penile modification (pasang tasbih in Indonesia and fang muk in Thailand $)^{9}$.

Prisons do not exist in isolation; prisoners come from, and return to, the broader community. Engagement in HIV risk behaviours such as unprotected $\operatorname{sex}^{10}$ and drug injecting ${ }^{11}$ shortly after release from prison is common. HIV positive prisoners, who may be unaware of their HIV status, risk passing the virus on to their sexual partners and those with whom they share injecting equipment. This was demonstrated in Thailand in the late 1980s. A prison amnesty was closely followed by a sharp increase in HIV prevalence among Bangkok's IDUs - from two per cent in 1987 to $43 \%$ in 1988. It is believed that many of the released inmates were HIV positive drug injectors who transmitted the virus to their sexual and injecting partners ${ }^{12}$. This example demonstrates that the failure to implement adequate HIV prevention and treatment programs in prison threatens the success of community-based efforts.

HIV prevalence in Nepal is estimated at $0.5 \%{ }^{13}$. Progress has been made at implementing HIV programs in community settings, but, as in most other countries, HIV in prisons has been neglected. The aim of this paper is to review HIV in prisons in Nepal, including general conditions as they relate to HIV and other infectious diseases; prevention programs such as education or condom distribution programs; and treatment and care programs such as free antiretroviral treatment.

\section{Materials and Methods}

The aim of the review was to collate relevant published and unpublished information from key experts relating to the response to HIV in prisons in Nepal. Specific information included three main areas:

1) General prison conditions

Correspondence

Ms Sarah Larney

NDARC, UNSW

Sydney NSW 2052

Australia

E-mail: s.larney@unsw.edu.au 
2) HIV testing, prevalence and risk behaviours,

3) HIV prevention, care and treatment.

The online databases Web of Science, Pubmed and Scopus were searched using the search string "(HIV or AIDS or HIV/AIDS) and prison and Nepal". Grey literature was accessed by searching the following websites: The International Centre for Prison Studies http://www.kcl.ac.uk/schools/law/research/icps; International AIDS Society http://www.iasociety. org/; UNAIDS http://www.unaids.org/en/; UNODC Regional Centre for South Asia http://www.unodc.org/ india/index.html; and WHO Regional Office for SouthEast Asia http://www.searo.who.int/.

Where gaps in the data remained, key experts were contacted via email or telephone and requests for specific information were made. Key experts included UN and other international agencies, NGOs working in prisons and/or the community in target countries and officials from relevant government ministries and prison administrative bodies.

\section{Results}

\section{Prisons in the National HIV/AIDS Strategy}

Prisoners are identified in the National HIV/AIDS Strategy as a 'vulnerable group' requiring targeted intervention. The Strategy acknowledges that once HIV is introduced into prisons, it can spread rapidly through sex and injecting drug use ${ }^{14}$. The objectives of the Strategy in relation to prisons are twofold: "to increase awareness and understanding among decision makers as regards HIV/AIDS/STI in prison" and "to ensure that every prisoner is aware of the risks of HIV/AIDS/STI and has the power and means to act on that knowledge"14. The draft National HIV/AIDS Programme budgets approximately US\$400,000 for prison-based HIV prevention, treatment and care activities ${ }^{15}$.

\section{Prison situation}

In 2008, the Home Ministry estimated there to be 6,700 people in prison in Nepal. Just over half of all inmates were unsentenced and awaiting trial ${ }^{16}$.

Accommodations, recreational and educational facilities in prisons are reported to be inadequate. Food is of poor quality and is insufficient to sustain good health ${ }^{17}$. In a survey of 57 women prisoners, $72 \%$ reported that the food provided in prison was insufficient for their needs ${ }^{18}$. Overcrowding is a major concern. In some prisons, overcrowding is so severe that toilet facilities are shared by men and women ${ }^{18}$.

General medical care is limited ${ }^{19}$, and access is impeded by the requirement in many cases that prisoners fund their own treatment ${ }^{18}$. A survey of 57 women prisoners found that only one third felt that medical care was "always available". Just over half felt that medical care was "usually available", while just over $10 \%$ said medical care was rarely or never available. It should be noted that although significant proportions of women felt that medical care was adequate, this must be seen in context. The women interviewed for this survey generally gave low priority to their health needs, evidenced by the finding that although three-quarters of the women surveyed said they were ill, one third of them had not requested medical attention ${ }^{18}$. Governmentprovided medical services are sometimes supplemented by services provided by $\mathrm{NGOs}^{20,21}$.

HIV prevalence and risk behaviours in prisons HIV prevalence among prisoners is not known. A rapid assessment of drug use and HIV carried out in 1999 found that drug injectors with a history of imprisonment were 4.6 times more likely to be HIV positive than those without such a history ${ }^{22}$.

The Ministry of Home Affairs has previously denied that sex occurs in prisons, because 'men are separated from women in prisons' ${ }^{22}$. However, more recent policy documents including the National HIV/AIDS Strategy and the National HIV/AIDS Action Plan and Budget acknowledge that prisoners engage in sexual activity and discuss the need for condom distribution in prisons ${ }^{14}$, ${ }^{23}$. The extent of sexual activity in prisons is unknown, however, one key expert has claimed that male-tomale sex in prison is 'very common'22. There has been a report of a female prisoner becoming pregnant and bearing a child after a sexual relationship with a male prisoner, suggesting that heterosexual activity is also occurring $^{18}$.

A study of five prisons in Eastern Nepal carried out indepth interviews with 95 inmates, of whom 27 (28\%) were drug users. It is unclear if they had access to and were using drugs in prison. Of the drug users, 75\% 'always' shared needles when injecting. Again, it is uncertain if this referred to behaviour in prison or in the community ${ }^{24}$. Prisoners caught using drugs are subjected to 'increased punishment', although it is unclear what form this may take ${ }^{22}$.

Policy documents acknowledge the lack of awareness of HIV risk behaviours in prison. The National HIV/ AIDS Action Plan for 2005-2006 lists "behavioural studies of prisoners" as an activity to be undertaken to remedy this situation ${ }^{23}$.

HIV testing in prisons

The National Centre for AIDS and STD Control guidelines for VCT state that mandatory HIV testing is not permitted in Nepal ${ }^{25}$. Prisoners are not included as a 
'priority group' for the provision of VCT services in the National HIV/AIDS Strategy ${ }^{14}$.

\section{HIV prevention interventions in prisons}

The National HIV/AIDS strategy includes sensitisation workshops for both prison officers and prisoners and condom distribution to enable prisoners to reduce the risk of sexually-transmitted HIV ${ }^{14}$. Training of staff and inmates has commenced on an ad-hoc basis ${ }^{26}$.

An education project carried out in one women's and two men's prisons in Kathmandu trained peer educators in HIV prevention and counselling. The peer educators helped to design and implement HIV education strategies suitable for prisons and distributed educational materials to other inmates ${ }^{27}$.

There are no dedicated drug dependency treatment, needle and syringe programs or bleach distribution programs in prison $^{28}$. According to a 1998 report, condoms were made available in two male prisons in $\mathrm{Kathmandu}^{27}$, but no more recent reports of condom distribution could be located. Both the National HIV/ AIDS Strategy and the National HIV/AIDS Action Plan include condom distribution as a program to be implemented $^{14,23}$.

\section{Treatment and care for HIV-infected prisoners}

No policy documents specify the provision of ART to prisoners as an activity for implementation and no information could be located on the assessment and treatment of co-infections.

\section{Discussion}

There is recognition in government policy documents that prisons and prisoners require greater attention if Nepal is to effectively stem the HIV epidemic. However, the information reviewed reveals that action is lacking. Nepal is not unique in this regard; prisons are often neglected in HIV prevention efforts ${ }^{29}$. This neglect threatens the success of community-wide HIV prevention efforts.

There have been some ad hoc HIV prevention efforts in prison, mostly education programs but also a condom distribution program. While small pilot projects such as these are useful for demonstrating the feasibility of an intervention, they can have little impact if not implemented on a broader scale. Attention should also be given to implementing a broader range of activities, including drug dependency treatment.

The National HIV/AIDS Strategy and National HIV/AIDS Action Plan and Budget provide a strong framework for the improvement of HIV prevention in prison. The activities outlined are vital to the development of an environment conducive to the implementation of further HIV prevention, treatment and care activities. Planned activities, if not already underway, should urgently be implemented.

The lack of discussion in the National Strategy around treatment and care for prisoners living with HIV is notable. This may in part relate to the lack of knowledge of HIV prevalence in prisons. This is an issue that must be addressed in order for the treatment and care needs of prisoners to be established. Voluntary counselling and testing should be made available to prisoners, and an anonymous, linked surveillance study could be conducted in several prisons. This would provide information valuable for planning future treatment and care service provision.

Given the limited resources available to implement HIV prevention, treatment and care programs in prison, government departments involved in prison management are encouraged to identify and collaborate with external partners such as NGOs to develop, seek funding for, implement and evaluate culturally appropriate HIV prevention, treatment and care programs.

Finally, interventions and legal reforms aimed at reducing the size of the prison population should be encouraged. Opioid substitution treatment has the potential to reduce criminal involvement among people who use heroin or other opiates, hence reducing prisoner numbers ${ }^{30}$. In terms of law reform, options for noncustodial sentences, such as community service orders for less serious offenders or mandated drug treatment for drug dependent offenders, should be explored.

\section{Acknowledgements}

This study was funded by the World Health Organization South East Asia Regional Office

\section{References}

1. Dolan K, Kite B, Black E, Aceijas C, Stimson GV. HIV in prison in low-income and middleincome countries. The Lancet Infectious Diseases. 2007;7:32-41.

2. Dolan K, Merghati Khoei E, Brentari C, Stevens A. Prisons and drugs: A global review of incarceration, drug use and drug services. UK: The Beckley Foundation Drug Policy Programme;2009.

3. Caplinskiene I, Caplinskas S, Griskevicius A. Narcotic abuse and HIV infection in prisons. Medicina. 2003;39(8):797-803.

4. Choopanya K, Des Jarlais DC, Vanichseni S, et al. Incarceration and risk for HIV infection among injection drug users in Bangkok. Journal of Acquired Immune Deficiency Syndromes. 2002;29(1):86-94. 
5. Dolan K, Hall W, Wodak A, Gaughwin M. Evidence of HIV transmission in an Australian prison. Medical Journal of Australia. 1994;160:734.

6. Taylor A, Goldberg DJ, Emslie J, et al. Outbreak of HIV infection in a Scottish prison. British Medical Journal. 1995;310:289-92.

7. Taussig J, Shouse RL, Fitzpatrick L, et al. HIV transmission among male inmates in a State prison system: Georgia, 1992-2005. Morbidity and Mortality Weekly Report. 2006;55(15):4216.

8. Buavirat A, Page-Shafer K, Van Griensven G, et al. Risk of prevalent HIV infection associated with incarceration among injecting drug users in Bangkok, Thailand: case-control study. British Medical Journal. 2003;326(7384):308-12.

9. Beyrer C, Jittiwutikarn J, Teokul W, et al. Drug use, increasing incarceration rates, and prisonassociated HIV risks in Thailand. Aids and Behavior. 2003;7(2):153-61.

10. MacGowan RJ, Margolis A, Gaiter J, et al. Predictors of risky sex of young men after release from prison. International Journal of STD \& AIDS. 2003;14(8):519-23.

11. Dolan K, Wodak A, Hall W, Gaughwin M, Rae F. HIV risk behaviour of IDUs before, during and after imprisonment in New South Wales. Addiction Research. 1996;4(2):151-60.

12. Wright NH, Vanichseni S, Akarasewi P, Wasi C, Choopanya K. Was the 1988 HIV epidemic among Bangkok's injecting drug-users a common source outbreak? AIDS. 1994;8:52932.

13. UNAIDS [homepage on the internet]. Epidemiological Fact Sheet on HIV and AIDS: Nepal. [cited on Jun 2009]. Available from: http://apps.who.int/globalatlas/ predefinedReports/EFS2008/full/EFS2008 NP.pdf. 14. NCASC. Nepal's National HIV/AIDS Strategy. Kathmandu: National Centre for AIDS and STI Control; 2002.

15. Steinberg M, Gilligan B, Rijal N, Pokharel B. Draft National HIV/AIDS Programme for Nepal (2003-2007). Kathmandu: National Centre for AIDS and STI Control; 2003.

16. International Centre for Prison Studies [homepage on the internet]. Prison Brief: Nepal.[cited on Jun 2009] . Available from http://www.kcl.ac.uk/depsta/law/research/icps/ worldbrief/wpb_country.php?country=106.

17. Ministry of Home Affairs Department of Prison Management. Department of Prison
Management Project: Project Document (Phase 1). Kathmandu: HMGN Ministry of Home Affairs; 2003.

18. Centre for Reproductive Law and Policy/Forum for Women Law and Development. Abortion in Nepal: Women imprisoned. Kathmandu: Centre for Reproductive Law and Policy; 2002.

19. CVICT. Nepal's Penal System: An Agenda for Change. Kathmandu: Centre for Victims of Torture; 2001.

20. CVICT [homepage on the internet]. Mobile health clinics in prison. [cited on sep 2006]. Available from: http://www.cvict.org.np/prison. html.

21. Sharma B, van Ommeren M. Preventing torture and rehabilitating survivors in Nepal. Transcultural Psychiatry. 1998;35:85-97.

22. FHI. Nepal HIV Drug Assessment Report. Kathmandu: Family Health International; 1999.

23. NCASC. National HIV/AIDS Action Plan and Budget 2005-06. Kathmandu: National Centre for AIDS and STI Control; 2005.

24. Paul C, Gupta SD, Sharma S, Deb M. Awareness, perception and risk behaviours of drug users in the prisons. Paper presented at: International Conference on AIDS, 2002; Barcelona.

25. NCASC. National Guidelines for Voluntary HIV/AIDS Counseling and Testing. Kathmandu: National Centre for AIDS and STI Control; 2003.

26. UNODC Regional Office for South Asia [homepage on the internet]. National Training Programmes in Nepal. [cited on Sep 2006]. Available from http://www.unodc.org/india/ nepal_info.html.

27. Upadhyay P. Challenge in implementing HIV/AIDS/STD in the prisons in Kathmandu, Nepal. Paper presented at: XII International AIDS Conference (Abstract no. 33586), 1998; Geneva.

28. UNODC Regional Office for South Asia. South Asia Regional Profile. New Delhi: UNODC Regional Office for South Asia; 2005.

29. UNODC/WHO/UNAIDS. HIV/AIDS Prevention, Care, Treatment and Support in Prison Settings. Vienna: United Nations Office on Drugs and Crime; 2006.

30. Shrestha DM. Methadone maintenance therapy in Nepal.2002. 